1 Research Group on Quality, Safety and Bioactivity of Plant Foods

2 Dept. Food Science and Technology

3 CEBAS-CSIC

4 Building 25, Campus de Espinardo, 30100, Murcia, SPAIN

Dear Nynke Hofstra,

12 Please find enclosed the second revision of the manuscript "Irrigating lettuce with 13 wastewater effluent: Does disinfection with chlorine dioxide inactivates viruses?" 14 submitted for publication in the Journal of Environmental Quality, to the special issue 15 "Microbial water quality: monitoring and modeling". The paper has been amended 16 following the editor and reviewer comments. We would like to thank the editor for the 17 valuable comments which have helped us to improve the quality of the manuscript.

19 Thank you for your consideration.

20 Yours sincerely,

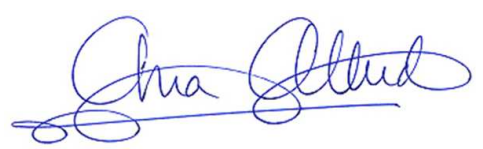

Ana Allende 
27

\section{Irrigating lettuce with wastewater effluent: Does disinfection with chlorine dioxide} inactivates viruses?

F. López-Gálvez ${ }^{1}$, W. Randazzo ${ }^{2,3}$, A. Vásquez ${ }^{4}$, G. Sánchez $^{2}$, L. Tombini Decol ${ }^{5}$, R. Aznar ${ }^{2,3}$, M.I. Gil ${ }^{1}$, Ana Allende ${ }^{1}$

${ }^{1}$ Research Group on Quality, Safety and Bioactivity of Plant Foods, Department of Food Science and Technology, CEBAS-CSIC, Campus Universitario de Espinardo, 25, 30100, Murcia, Spain.

${ }^{2}$ Department of Biotechnology, IATA-CSIC, Av. Agustín Escardino, 7, 46980, Valencia, Spain.

${ }^{3}$ Departament of Microbiology and Ecology, University of Valencia. Av. Dr. Moliner, 50. 46100 Burjassot. Valencia. Spain.

${ }^{4}$ Faculty of Animal Science and Food Engineering, University of São Paulo, Av. Duque de Caxias Norte, 225. 13635-900 Pirassununga, São Paulo, Brazil.

${ }^{5}$ Laboratório de Microbiologia e Controle de Alimentos, Instituto de Ciência e Tecnologia de Alimentos, Universidade Federal do Rio Grande do Sul (ICTA/UFRGS). Av. Bento Gonçalves 9.500, prédio 43212, Campos do Vale, Agronomia, CEP: 91501970, Porto Alegre/RS, Brazil.

*Corresponding author: Dr. Francisco López-Gálvez. E-mail: flopez@cebas.csic.es 


\section{Core Ideas}

49 - Reclaimed water used for irrigation can contain enteric viruses.

50 - Current detection methods do not distinguish infectious from non-infectious 51 viruses.

52 - PMAxx treatment can help to get information on the infectivity of viral particles.

53 - Treatment of reclaimed water with chlorine dioxide did not improve irrigation 54 water safety. 


\section{Abstract}

Reclaimed water obtained from urban wastewater is currently being used as irrigation water in water-scarce regions in Spain. However, wastewater can contain enteric viruses that water-reclamation treatment cannot remove or inactivate completely. In the present study, greenhouse-grown baby lettuce was irrigated with secondary treatment effluent from a wastewater treatment plant untreated and treated using chlorine dioxide $\left(\mathrm{ClO}_{2}\right)$. The effect of $\mathrm{ClO}_{2}$ treatment on the physicochemical characteristics and the presence of enteric viruses in irrigation water and lettuce was assessed. Presence of human noroviruses genogroups I and II (NoV GI and NoV GII), and human astroviruses (HAstV), was analyzed by real-time PCR (RT-qPCR). Additionally, to check for the loss of infectivity induced by the disinfection treatment, positive samples were re-analyzed after pre-treatment with the intercalating dye PMAxx before RNA extraction and RT-qPCR. There were no significant differences in the proportion of positive samples and the concentration of enteric viruses between treated and untreated reclaimed water without PMAxx pre-treatment $(\mathrm{p}>0.05)$. A significantly lower concentration of $\mathrm{NoV}$ GI was detected in $\mathrm{ClO}_{2}$-treated water when samples were pretreated with PMAxx $(\mathrm{p}<0.05)$, indicating that inactivation was due to the disinfection treatment. Laboratory-scale validation tests indicated the suitability of PMAxx-RTqPCR for discrimination between potentially infectious and $\mathrm{ClO}_{2}$-damaged viruses. Although the applied $\mathrm{ClO}_{2}$ treatment was not able to significantly reduce the enteric virus load of the secondary effluent from the wastewater treatment plant, none of the lettuce samples analyzed $(n=36)$ was positive for the presence of NoV or HAstV.

Keywords: wastewater; norovirus; astrovirus; vegetables; irrigation water; infectivity. 


\section{Introduction}

Access to adequate water quality is challenging in several regions of the world, and the situation is expected to worsen as climate change exacerbates water scarcity. Water recycling and reuse is a strategy to save water resources. In some parts of the world, water reclaimed from wastewater will need to be used for irrigation to sustain agriculture (Becerra-Castro et al., 2015). Among other human pathogens, enteric viruses can be found in the aquatic environment, mainly by the discharge of wastewater treatment plant (WWTP) effluents or the failure of depuration processes (Morsy et al., 2007; Hewitt et al., 2011; Rusiñol et al., 2015).

In the growing trend in foodborne outbreaks associated with the consumption of leafy greens, irrigation water is usually suspected as the main contamination source ( $\mathrm{Li}$ et al., 2015). Presence of human norovirus (NoV) and human astroviruses (HAstV) in irrigation water is one cause of fresh produce contamination with these pathogenic microorganisms (Bosch et al., 2014; Van Haute et al., 2015). Viruses present in contaminated irrigation water can attach to leaf surfaces and survive at the pre-harvest step (Wei et al., 2010; Hirneisen and Kniel, 2013). Moreover, other studies conducted on soil-grown lettuce and strawberry reported the internalization of NoV surrogates via plant roots from contaminated soils and the subsequent dissemination to the leaves and fruits (DiCaprio et al., 2015a, 2015b).

Disinfection is a mitigation strategy that can be used to reduce the health risk associated with the presence of microbial pathogens in irrigation water, although little information is available on its effectivity on human enteric viruses (Hamilton et al., 2006). One of the disinfection technologies that can be applied for irrigation water is chlorine dioxide $\left(\mathrm{ClO}_{2}\right)$ (Reitz et al. 2015), which has the advantage of not forming organohalogen by-products and is a more powerful oxidant than sodium hypochlorite (Gómez-López et al. 2009; López-Gálvez et al., 2010). Chlorine-washing procedures are reported to be almost ineffective in removing human NoV surrogates from fresh produce (Cromeans, 2014; DiCaprio, 2015c), while several studies have reported the sensitivity of a range of viruses to $\mathrm{ClO}_{2}$ (Butot et al., 2008; Jin et al., 2012; Lim et al., 2010; Li et al., 2015; Xue et al., 2013). However, no information on HAstV has been reported so far.

Currently, real-time RT-PCR (RT-qPCR) is the gold-standard method for the detection and quantification of enteric viruses in water and food samples (Bosch et al., 
2011). In 2017, ISO 15216 was released as standard procedure for hepatitis A virus (HAV) and NoV detection in food and bottled water (International Organization for Standardization, 2017). However, this technique cannot distinguish between infectious and non-infectious viral particles (Knight et al., 2013; Hamza et al., 2011). For instance, Lim et al. (2010), reported that the virus inactivation by $\mathrm{ClO}_{2}$ measured by cell culture using norovirus surrogates did not correlate with short and long template RT-PCR assays, resulting in a significant underestimation of the inactivation. Thus, to assess viral infectivity by RT-qPCR, some authors recommend the use of intercalating dyes such as ethidium monoazide (EMA), propidium monoazide (PMA) or PMAxx (Coudray-Meunier et al., 2013; Prevost et al., 2016; Randazzo et al., 2016, 2017). The application of intercalating dyes has been proposed as a strategy for a better interpretation of quantitative results in terms of viral infectivity in foods (Moreno et al., 2015; Randazzo et al., 2016, 2018a,b) and different types of water samples (Fuster et al., 2016; Parshionikar et al., 2010; Quijada et al., 2016; Randazzo et al., 2016, 2017).

The aim of the present study was to assess $\mathrm{ClO}_{2}$ disinfection of a secondary effluent of wastewater used for lettuce irrigation. We examined: (i) occurrence of NoV and HAstV in irrigation water, (ii) NoV and HAstV inactivation in irrigation water, and (iii) occurrence of NoV and HAstV in lettuce.

\section{Material and Methods}

\section{Experimental setup}

Red oak leaf lettuce (Lactuca sativa, L.) was grown in trays of 294 alveoli with peat as substrate. Greenhouse characteristics and irrigation system were described previously in López-Gálvez et al. (2016). Irrigation wastewater of two qualities was compared: untreated secondary effluent from a wastewater treatment plant (WWTP; secondary wastewater treatment was performed as described in López-Gálvez et al., 2016) and $\mathrm{ClO}_{2}$-treated water from the same source. A total of eight lettuce trays with 294 plants each were used per water type in each trial, and two trials were performed between June and August 2016. Minimum and maximum temperatures inside the greenhouse were $26.7^{\circ} \mathrm{C}$ and $32.2^{\circ} \mathrm{C}$, with an average of $28.1 \pm 1.5^{\circ} \mathrm{C}$. The relative humidity $(\mathrm{RH})$ in the greenhouse ranged from $55.1 \%$ to $99.9 \%$, with an average of $80.8 \pm 10.2 \%$. Irrigation water applied at $\approx 300 \mathrm{~L} / \mathrm{d}$ in two irrigation periods of $20 \mathrm{~min}$ 
each. The growth cycle of baby lettuce lasted 38 days in the first trial (June-July), and 26 days in the second trial (July-August).

Water samples were taken weekly during the whole growth cycle. Due to the small plant size, samples of baby lettuce were taken weekly starting two weeks before harvest. Each sampling day, two water samples of each type of water and three lettuce samples per water type were taken. Water samples $(2 \mathrm{~L})$ were taken in 2.7-L aseptic plastic bottles. Sodium thiosulfate was added to the $\mathrm{ClO}_{2}$-treated water to quench residual disinfectant. Lettuce samples (100 g) were taken in aseptic conditions and placed in plastic bags. Water and lettuce samples were transported to the lab in refrigerated conditions. A total of 24 water samples (12 per water type) and 36 lettuce samples (18 per water type), from the two trials combined, were analyzed for the presence of NoV (GI and GII) and HAstV.

\section{$\mathrm{ClO}_{2}$ treatment and physicochemical analysis of water}

A concentrated solution of $\mathrm{ClO}_{2}(\approx 6000 \mathrm{mg} / \mathrm{L})$ AGRI DIS ${ }^{\circledR}$ was diluted to 100 $300 \mathrm{mg} / \mathrm{L} \mathrm{ClO}_{2}$ using tap water in a 20 -L opaque plastic tank according to manufacturer instructions (Servicios Técnicos de Canarias, Las Palmas de Gran Canaria, Spain). $\mathrm{ClO}_{2}$-treated water was prepared at the irrigation head and dosed using a peristaltic pump for treating the secondary effluent of the WWTP. The leftover diluted solution was disposed daily before performing the first irrigation, and a new one was prepared. Time lapse from the $\mathrm{ClO}_{2}$ application point to the sprinklers (contact time) was about 6 min. To avoid interference from the water remaining in the irrigation system from previous irrigations, a protocol was established before each irrigation event. First, trays were removed from the tables, and then the system was filled with freshly treated water and the irrigation started for a few minutes. Then, the irrigation was stopped, the trays were returned to the tables, and the irrigation started again. Chlorine dioxide measurements were carried out daily by chronoamperometry analysis (Palintest, Gateshead, UK) in untreated and $\mathrm{ClO}_{2}$-treated water samples taken during irrigation at the sprinklers. Temperature, $\mathrm{pH}$, and ORP were measured with a multimeter $(\mathrm{pH}$ and redox 26, Crison, Barcelona, Spain). Water filtered through $0.45-\mu \mathrm{m}$ syringe nylon filters (Fisherbrand-Fisher Scientific, Waltham, USA) was used for measuring the absorbance at $254 \mathrm{~nm}$ using a UV-VIS spectrophotometer (Jasco V-630, Tokyo, Japan) and quartz cuvettes with a path length of $1 \mathrm{~cm}$ (Hellma, Müllheim, Germany). Total organic carbon (TOC) was assessed using a multi N/C 3100 analyzer (Analytik Jena, 
Jena, Germany) after filtration through ashless filter paper (Albet Labscience, Dassel, Germany).

\section{NoV and HAstV analysis in water}

Recovery of viruses from water was performed as described in López-Gálvez et al. (2016). Briefly, magnesium chloride $\left(\mathrm{MgCl}_{2}\right)$ was added to each water sample and $\mathrm{pH}$ was adjusted to 3.5 with hydrogen chloride $(\mathrm{HCl})$. Samples of $200 \mathrm{~mL}$ were filtered through $0.45-\mu \mathrm{m}$ membrane filters (Sartorius, Göttingen, Germany). Filters were then transferred to sterile tubes containing $5 \mathrm{~mL}$ of elution buffer, and $\mathrm{pH}$ was adjusted to 9.5 using sodium hydroxide $(\mathrm{NaOH})$. Tubes were shaken for 1 min in a vortex, kept for 4 min in an ultrasonic bath, and shaken again in a horizontal orbital shaker at $250 \mathrm{rpm}$ for $10 \mathrm{~min}$, and then $\mathrm{pH}$ was adjusted to 7 using $\mathrm{HCl}(10 \%)$. After that, samples were kept at $-70{ }^{\circ} \mathrm{C}$ until analysis. To monitor the virus concentration procedure and RNA extraction, $200 \mathrm{~mL}$ of each secondary effluent water sample was spiked with a known concentration of mengovirus M0 strain prior to processing as process control virus following ISO 15216 guidelines (International Organization for Standardization, 2017; Costafreda et al., 2006). RNA extraction was performed using the NucleoSpin ${ }^{\circledR}$ RNA virus kit (Macherey-Nagel GmbH \& Co.) according to the manufacturer's instructions and with the plant RNA isolation aid treatment as detailed in Randazzo et al. (2016). Human NoV and HAstV genome copies were quantified in duplicate by one-step RTqPCR assay using the RNA UltraSense One-Step quantitative system (Invitrogen SA) with a half-scale modification of the manufacturer's protocol and the LightCycler 480 instrument (Roche Diagnostics) following the standardized ISO procedure (ISO 152161:2017, International Organization for Standardization, 2017) for NoVs, and the primers and probe for HAstV as suggested by Sano et al. (2010).

Additionally, positive samples for NoV GI, NoV GII, or HAstV were extracted again, and a PMAxx-Triton pretreatment was applied in parallel before RNA extraction (Randazzo et al., 2016). Briefly, $100 \mu \mathrm{l}$ of concentrated samples was mixed with $50 \mu \mathrm{M}$ PMAxx and $0.5 \%$ Triton (PMAxx-Triton), incubated in the dark at room temperature for $10 \mathrm{~min}$ in a shaker at $150 \mathrm{rpm}$, and immediately exposed to continuous LED light (Led-Active Blue, GenIUL) for 15 min. After intercalating-dye pretreatment, RNA was extracted using the NucleoSpin ${ }^{\circledR}$ RNA virus kit according to the manufacturer's instructions. RT-qPCR was performed as described above. As a control, $100 \mu \mathrm{l}$ of 
212 concentrated water samples was processed without performing the PMAxx-Triton 213 pretreatment.

214

215

216

217

218

219

220

221

222

223

224

225

226

227

228

229

230

231

232

233

234

235

236

237

238

239

240

241

242

243

244

245

\section{NoV and HAstV analysis in baby lettuce}

Recovery of viruses from fresh produce samples was performed as described in López-Gálvez et al. (2016), with some modifications. Briefly, lettuce samples (25 g) were placed in sterile stomacher bags with filter and soaked in $40 \mathrm{~mL}$ of elution buffer for $20 \mathrm{~min}$ at room temperature with constant shaking. The fluid was recovered from the bag and centrifuged at $8500 \mathrm{~g}$ for $30 \mathrm{~min}$ at $4{ }^{\circ} \mathrm{C}$. Then, $\mathrm{pH}$ of the decanted supernatant was adjusted to $7.2 \pm 0.2$ using HCl. Polyethylene glycol (PEG) 6000 (Acros Organics, Geel, Belgium) and sodium chloride ( $\mathrm{NaCl}$ ) (Panreac Química, Barcelona, Spain) were added to the neutralized supernatant. Subsequently, fluid was incubated for $2 \mathrm{~h}$ at $4{ }^{\circ} \mathrm{C}$. Viruses were concentrated by centrifuging the solution at $8500 \mathrm{~g}$ for $30 \mathrm{~min}$ at $4{ }^{\circ} \mathrm{C}$. The supernatant was discarded, and additional centrifugation was carried out at $8500 \mathrm{~g}$ for $5 \mathrm{~min}$ at $4{ }^{\circ} \mathrm{C}$ to compact the pellet. The pellet was finally re-suspended in $1 \mathrm{~mL}$ of phosphate-buffered saline and stored at $-75^{\circ} \mathrm{C}$ before RNA extraction. Mengovirus was added as process control. RNA extraction and RT-qPCR reactions from lettuce samples were performed as described above for water samples.

Performance of PMAxx pretreatment to predict viral inactivation in PBS and secondary effluent waters treated with $\mathrm{ClO}_{2}$

A test was performed to validate the suitability of the PMAxx treatment to predict viral inactivation under the experimental conditions used. Fecal samples containing NoV GI genotype 4 (GI·P4) and GII genotype 4 (GII.4 variant Den Haag 2006b), and HAstV were suspended (10\%, wt/vol) in phosphate-buffered saline (PBS) containing 2 $\mathrm{M} \mathrm{NaNO}_{3}$ (Panreac), $1 \%$ beef extract (Conda), and $0.1 \%$ Triton X-100 (Fisher

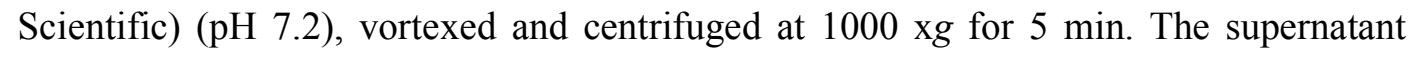
was used to inoculate 500-mL aliquots of PBS ( $\mathrm{pH} 7.2)$ and a WWTP secondary treatment effluent. $\mathrm{ClO}_{2}$ was added to achieve an initial concentration of 5.5 or 11 $\mathrm{mg} / \mathrm{L}$, and samples were incubated for $6 \mathrm{~min}$ at room temperature $\left(\approx 25^{\circ} \mathrm{C}\right)$ under agitation on a magnetic stirrer $(300 \mathrm{rpm})$. After the contact time of 6 min, sodium thiosulfate $(2.75 \mathrm{~g} / \mathrm{L})$ was added to neutralize $\mathrm{ClO}_{2} \cdot \mathrm{ClO}_{2}$ concentration was measured by chronoamperometry using a portable device (Chlordioxense; Palintest, Gateshead, UK). Aliquots of inoculated untreated PBS and secondary wastewater were kept at 
room temperature as a control. Viral inactivation was determined by examining the loss of genome copy titers by comparing RT-qPCR and PMAxx-RTqPCR as described above. Physicochemical characteristics of treated PBS and secondary water were also assessed. $\mathrm{pH}$, temperature and ORP were monitored during the treatment using a portable multimeter (sensION+ MM150, Hach, Loveland, Colorado, USA). Absorbance at $254 \mathrm{~nm}$ of secondary wastewater was measured as explained above. Chemical oxygen demand of secondary water was measured by the standard photometric method (APHA, 2012).

\section{Statistical analysis}

$\mathrm{NoV}$ and HAstV quantification was adjusted with the mengovirus recovery for each sample (Costafreda et al., 2006). In particular, final NoV and HAstV concentrations were corrected by taking into account the recovery of mengovirus calculated before and after the concentration and extraction steps for each type of water. Thus, NoV and HAstV titers were log-transformed and introduced in a Microsoft Excel 2010 spreadsheet (Microsoft, Redmond, WA, USA). IBM SPSS statistics 20 (IBM, Armonk, NY, USA) was used for statistical analysis. The Kolmogorov-Smirnov test and Levene's test were used to assess normality and equality of variance, respectively. When normality could be assumed, a t-test was performed to evaluate differences. When data did not follow a normal distribution, non-parametric tests were applied. To compare the prevalence of positive samples for viruses between $\mathrm{ClO}_{2}$ treated and untreated irrigation water, the chi-square $\left(\chi^{2}\right)$ test was used.

\section{Results and Discussion}

$\mathrm{ClO}_{2}$ treatment and physicochemical characteristics of irrigation water

The doses of $\mathrm{ClO}_{2}$ that were applied were selected based on preliminary tests with the aim of reaching levels of Escherichia coli in the water below $2 \log \mathrm{cfu} / 100 \mathrm{~mL}$, which corresponds to the $E$. coli threshold recommended in several GAP guidelines for irrigation water $(\mathrm{EC}, 2017)$. To achieve this goal, the initial $\mathrm{ClO}_{2}$ concentration in treated water ranged between 3 and $11 \mathrm{mg} / \mathrm{L}$. Mean residual $\mathrm{ClO}_{2}$ concentration in $\mathrm{ClO}_{2}$ treated irrigation water at the sprinklers was $0.53 \pm 0.40$ and $0.42 \pm 0.43 \mathrm{mg} / \mathrm{L}$ in the first and the second growing cycles, respectively. The average residual concentration adjusted was close to the recommended dose for the continuous application in 
279 greenhouse production (WEAH, 2016). The residual concentration of $\mathrm{ClO}_{2}$ in the 280 treated water varied between 0.04 and $1.28 \mathrm{mg} / \mathrm{L}$, and between 0.03 and $1.51 \mathrm{mg} / \mathrm{L}$ in 281 the first and the second trials, respectively. The observed variation in the residual concentration can be attributed to the differences in the sanitizer demand by the secondary effluent provided by the WWTP. The $\mathrm{ClO}_{2}$ treatment did not change the physicochemical characteristics of the irrigation water significantly (Table 1). The average temperature of the water was similar to the average temperature measured inside the greenhouse $\left(\approx 28^{\circ} \mathrm{C}\right)$. Although the presence of oxidants has been reported to increase both ORP and UV254 (APHA, 2012), no significant differences in these parameters were detected in the present study between $\mathrm{ClO}_{2}$-treated and untreated water (Table 1). In contrast, higher ORP and UV254 values have been reported for $\mathrm{ClO}_{2}$ treated irrigation water even though the $\mathrm{ClO}_{2}$ residuals were lower than those detected in the present study (López-Gálvez et al., 2018). These differences could be due to differences in water-quality characteristics between the surface water from the mentioned study and the reclaimed water from the present study.

\section{Occurrence of viruses in irrigation water}

All the water samples were positive for the sample process control (Mengovirus) with a percent of recovery of $48.2 \pm 22.9 \%$. Da Silva et al. (2007) reported extraction efficiencies generally above $10 \%$ of mengovirus in wastewater samples. The occurrence of NoV GI, NoV GII, and HAstV in untreated and $\mathrm{ClO}_{2}$-treated water samples analyzed without PMAxx pre-treatment is shown in Table 2. Comparing both NoV genogroups in untreated water samples, the concentration of NoV GII was significantly higher than that of NoV GI $(p<0.05)$. In contrast, levels of NoV GI have been reported to be higher than those of NoV GII (López-Gálvez et al., 2016). This difference highlights the temporal fluctuations in virus concentration in WWTP effluents. Kitajima et al. (2014) observed in a 1-year study that in some months there was a higher concentration of NoV GI compared to NoV GII in WWTP effluent, while in other months the reverse was true. On the other hand, in untreated water, there was a higher percentage of samples positive for NoV GI than for NoV GII (Table 2). The same relationship was observed in a secondary effluent in a previous study (López-Gálvez et al., 2016). In the present study, treatment of secondary effluent with $\mathrm{ClO}_{2}$ reduced the proportion of samples positive for NoV GI and GII (Table 2). However, there was no significant difference in the concentration of $\mathrm{NoV}$ between untreated and $\mathrm{ClO}_{2}$-treated samples $(\mathrm{p}>0.05)$. As in 
our study, Katayama et al. (2008) did not detect differences in NoV levels between secondary treated wastewater and WWTP effluent (chlorinated) samples. In the case of $\mathrm{HAstV}$, there was no difference in the percentage of positive samples between untreated and $\mathrm{ClO}_{2}$-treated water samples (Table 2). Similar results were recently reported by Kobayashi et al. (2017), where a down-flow hanging sponge (DHS) reactor for the treatment of effluent was evaluated as a source of water for agricultural irrigation. They reported the presence of HAstV in $36 \%$ and $32 \%$ of influent and effluent water samples analyzed, respectively. RT-qPCR is not able to distinguish between infectious and noninfectious viruses (Knight et al., 2013), which could explain the lack of differences in the virus concentration between untreated and $\mathrm{ClO}_{2}$-treated water samples.

\section{Potential infectivity of viruses in irrigation water}

The protocol used in the present study was demonstrated to be appropriate to reduce the RT-qPCR signal of HAV, NoV GI and NoV GII in irrigation and wastewater samples (Randazzo et al., 2016; Randazzo et al., 2018ab). Some authors reported pretreatment with intercalating dyes (e.g. PMA, PMAxx) coupled with RT-qPCR as a useful tool to rapidly assess the infectivity of enteric viruses in water inactivated by heat-treatments (Randazzo et al., 2016, 2017) or chemical disinfectants (Parshionikar et al., 2010; Leifels et al., 2015; Fuster et al., 2016). However, when the present study was performed, the suitability of PMA-RT-PCR to assess the inactivation of $\mathrm{ClO}_{2}$-treated viruses had not been confirmed by previous studies.

The two $\mathrm{ClO}_{2}$ concentrations tested in our lab-scale study represented the average $(\approx 5.5 \mathrm{mg} / \mathrm{L})$ and the highest initial levels $(\approx 11 \mathrm{mg} / \mathrm{L})$ of $\mathrm{ClO}_{2}$ applied during the greenhouse tests. Figure 1 shows the concentration of viral genomes detected by RT-qPCR and by PMAxx-RT-qPCR after $\mathrm{ClO}_{2}$ treatment was performed in PBS and secondary treatment effluent waters. Results show the ability of PMAxx pretreatment in discriminating potentially infectious and $\mathrm{ClO}_{2}$-damaged viruses. Comparing the results obtained by RT-qPCR and PMAxx-RT-qPCR in $\mathrm{ClO}_{2}$-treated PBS suspensions (Fig. 1A), it could be concluded that PMAxx pretreatment allowed detection of the effect of $\mathrm{ClO}_{2}$ treatment on the integrity of viral structure. This effect was significant in NoV GI and GII for the two $\mathrm{ClO}_{2}$ concentrations tested, whereas it was significant in HAstV only for the highest disinfectant concentration (11 mg/L). Wiggington et al. (2012) and Sigstam et al. (2013) reported extensive degradation of viral proteins by chlorine 
346 dioxide, while Yeap et al. (2016) showed that $\mathrm{ClO}_{2}$ inactivation of murine norovirus 347 included disruption of viral structure.

348 When $\mathrm{ClO}_{2}$ treatments were applied to viral suspensions prepared using 349 secondary treatment effluent water at lab scale, the results obtained were different from 350 those obtained in PBS suspensions. The comparison of the results obtained by RT351 qPCR and PMAxx-RT-qPCR in $\mathrm{ClO}_{2}$-treated secondary effluent suspensions (Fig. 1B) 352 suggests that the integrity of the viral structure was damaged in the case of NoV GII for 353 both $\mathrm{ClO}_{2}$ concentrations, while it was affected only by the highest concentration for 354 HAstV and NoV GI.

355 The difference in the results obtained in PBS and secondary effluent water could 356 have been caused by the different disinfectant demand of these two media. The higher $357 \mathrm{ClO}_{2}$ demand of secondary effluent water caused a larger decrease in $\mathrm{ClO}_{2}$ 358 concentration during treatment (Supplementary information 1). With less disinfectant 359 available, the damage on the viral capsid would have been milder in the secondary 360 effluent water compared with PBS. Kingsley et al. (2014) suggested that human 361 noroviruses are quite resistant to different disinfectants, including $\mathrm{ClO}_{2}$. They observed 362 only a $2.8 \mathrm{log}$ reduction in human norovirus after a 60 -min treatment with $350 \mathrm{ppm}$ 363 chlorine dioxide. In contrast, in our study, reductions of 5 to $6 \log$ units in NoV GI and 364 GII were obtained by treating PBS with an initial dose of $5.5 \mathrm{mg} / \mathrm{L} \mathrm{ClO}_{2}$. However, as 365 explained before, smaller reductions were detected when secondary effluent water was 366 treated.

Regarding the greenhouse tests, Table 3 shows the concentrations (log genome copies/L) of NoV GI and GII in water samples positive for the presence of NoV and HAstV that were re-analyzed with and without PMAxx-Triton pre-treatment. In the case of $\mathrm{ClO}_{2}$-treated secondary effluent water, the concentration of NoV GI in PMAxxTriton pretreated samples was significantly lower $(\mathrm{p}<0.01)$ than non-pretreated samples (Table 3), indicating that the capsid of viruses was damaged due to disinfection with $\mathrm{ClO}_{2}$. However, no significant differences were observed for NoV GII and HAstV $(\mathrm{p}>0.05)$, indicating that the viral particles remained uninjured after the disinfection treatment with $\mathrm{ClO}_{2}$. As could be expected, no significant differences were observed for NoV and HAstV between PMAxx-pretreated and non-pretreated samples in untreated irrigation water (Table 3). In a previous study, RT-qPCR signal of NoV GII was more 
easily removed than the signal of NoV GI using the PMAxx pretreatment, which was attributed to a better environmental persistence of NoV GI (Randazzo et al. 2016).

Sales-Ortells et al. (2014) assessed the health risks derived from consumption of lettuces irrigated with tertiary effluent containing norovirus in Catalonia (Spain), stating that reductions of $4.3 \log$ should be ensured to reduce the disease burden to $10^{-6}$ Disability Adjusted Life Years (DALYs) per person per year, as recommended (WHO, 2006). In the present study, a maximum reduction of $0.65 \log$ for NoV GI in secondary treatment effluent water was detected by PMAxx-RT-qPCR during the greenhouse tests. In the lab-scale tests, the reductions obtained in secondary effluent water were higher, but were still far from the target of $4.3 \mathrm{log}$.

\section{Occurrence of viruses in lettuce}

All the analyzed lettuce samples were positive for the mengovirus process control, with average recoveries of $10.2 \pm 8.5 \%$, in accordance with the ISO 15216 recommendations (International Organization for Standardization, 2017), which establishes acceptable recoveries greater than 1\%. In line, Hennechart-Collette et al. (2015) reported similar recoveries of mengovirus from lettuce $(10.8 \%)$. In the present study, no lettuce samples positive for NoV GI, NoV GII, or HAstV $(n=36)$ were observed. As viruses were detected in irrigation water and they can survive in preharvest conditions, such results were unexpected, especially taking into account the sprinkler irrigation system used (Hirneisen and Kniel, 2013). The lack of positive results in lettuce could be explained by the low recovery rates compared with those obtained in water samples. Furthermore, the protocol used for virus recovery could not detect internalized viral particles if present. Pérez-Rodríguez et al. (2014) detected two positive samples for NoV GI and four positive samples for NoV GII when analyzing 60 lettuce samples (both unprocessed and ready-to-eat lettuce), which corroborates the low prevalence in fresh produce. In accordance with these results, Kokkinos et al. (2012) found only two positives out of 149 samples of lettuce analyzed for NoV GI, and one positive sample out of 126 of lettuce analyzed for NoV GII. Baert et al. (2011) found 186 samples positive for NoV out of 653 samples (28.5\%). Furthermore, at temperatures as high as those observed during the trials, high reduction of virus titers in fresh produce surfaces was expected (3-4 log at $30{ }^{\circ} \mathrm{C}$ in 24 h; Carratalà et al., 2013). 


\section{CONCLUSIONS}

412

RT-qPCR analysis of water samples without PMAxx pretreatment did not show significant differences in virus load between non-disinfected and $\mathrm{ClO}_{2}$-disinfected secondary effluent. A lab-scale validation experiment confirmed the ability of PMAxx pretreatment in discriminating enteric viruses inactivated by $\mathrm{ClO}_{2}$. Pretreatment using PMAxx and Triton significantly reduced the RT-qPCR signals of NoV GI in $\mathrm{ClO}_{2}$ treated water when compared to the non-pretreated samples. This could indicate virus inactivation by $\mathrm{ClO}_{2}$. For NoV GII and HAstV these differences were not detected, suggesting lack of viral inactivation in water samples. In our study, the $\mathrm{ClO}_{2}$ treatment was only minimally effective in reducing the load of enteric viruses in reclaimed water assessed by RT-qPCR coupled with PMAxx pretreatment. However, NoV and HAstV could not be detected in the lettuce irrigated with contaminated water, probably due to the limited recovery achieved. In any case, $\mathrm{ClO}_{2}$ treatment should be optimized to achieve the reductions needed to make reclaimed water microbiologically safe for its use in irrigation (e.g., using longer contact times or higher $\mathrm{ClO}_{2}$ doses). The efficacy of the water-disinfection treatments should be assessed using novel techniques that allow differentiation between infectious and non-infectious viral particles.

\section{Acknowledgments}

Authors are thankful for the financial support from the Center for Produce Safety Grant Agreement (Projects 2015-374 and 2017-01), the MINECO (Projects AGL201348529-R and AGL2016-75878-R) and the Spanish National Institute for Agriculture and Food Research and Technology (INIA) co-financed by the European Social Fund (Project RTA2014-00024-C03). Financial support has been co-sponsored by the European Regional Development Fund (FEDER). Support provided by the Fundación Séneca (19900/GERM/15) and Proyecto Intramural 201670E056 is also appreciated. This work was carried out during a scholarship supported by the Doctoral Program Sandwich Exterior (PDSE), process number 88881.132189 / 2016-01, financed by CAPES - Brazilian Federal Agency for Postgraduate Support and Evaluation at the Brazilian Ministry of Education. We also thank Dr. Albert Bosch (University of Barcelona, 
Spain) for providing the Mengovirus M0 strain, and Dr. Buesa (University of Valencia, Spain)

442 for providing the fecal samples.

\section{References}

445

446

447

448

449

450

451

452

453

454

455

456

457

458

459

460

APHA (American Public Health Association). 2012. Standard Methods for the Examination of Water and Wastewater, 22th ed. American Public Health Association, Washington, D.C.

Baert, L., K. Mattison, F. Loisy-Hamon, J. Harlow, A. Martyres, B. Lebeau, et al. 2011. Review: Norovirus prevalence in Belgian, Canadian and French fresh produce: A threat to human health? Int. J. Food Microbiol. 151:261-269.

Becerra-Castro, C., Lopes, A.R., Vaz-Moreira, I., Silva, E.F., Manaia, C. M., Nunes, O.C., 2015. Wastewater reuse in irrigation: A microbiological perspective on implications in soil fertility and human and environmental health. Environ. International, 75, 117-135.

Bosch, A., R.M. Pintó, and S. Guix. 2014. Human Astroviruses. Clin. Microbiol. Rev. 27:1048-1074.

Bosch, A., G. Sánchez, M. Abbaszadegan, A. Carducci, S. Guix, F. Le Guyader, et al. 2011. Analytical methods for virus detection in water and food. Food Anal. Method. 4:4-12.

Butot, S., T. Putallaz, and G. Sánchez. 2008. Effects of sanitation, freezing and frozen storage on enteric viruses in berries and herbs. Int. J. Food Microbiol. 126:30-5.

Carratalà, A., J. Rodriguez-Manzano, A. Hundesa, M. Rusiñol, S. Fresno, N. Cook, and R. Girones. 2013. Effect of temperature and sunlight on the stability of human adenoviruses and MS2 as fecal contaminants on fresh produce surfaces. Int. J. Food Microbiol. 164:128-134.

Costafreda, M.I., A. Bosch, and R.M. Pintó. 2006. Development, evaluation, and standardization of a real-time TaqMan reverse transcription-PCR assay for quantification of hepatitis A virus in clinical and shellfish samples. Appl. Environ. Microb. 72:3846-3855. 
470 Coudray-Meunier, C., A. Fraisse, S. Martin-Latil, L. Guillier, and S. Perelle. 2013. 471 Discrimination of infectious hepatitis A virus and rotavirus by combining dyes 472 and surfactants with RT-qPCR. BMC Microbiol. 13:216.

473 Cromeans, T., G.W. Park, V. Costantini, D. Lee, Q. Wang, T. Farkas, et al. 2014. 474 Comprehensive comparison of cultivable norovirus surrogates in response to 475 different inactivation and disinfection treatments. Appl. Environ. Microb. $476 \quad 80: 5743-5751$.

Da Silva, A.K., J.-C. Le Saux, S. Parnaudeau, M. Pommepuy, M. Elimelech, and F.S.

DiCaprio, E., D. Culbertson, and J. Li. 2015a. Evidence of the internalization of animal caliciviruses via the roots of growing strawberry plants and dissemination to the fruit. Appl. Environ. Microb. 81:2727-2734.

DiCaprio, E., A. Purgianto, and J. Li. 2015b. Effects of abiotic and biotic stresses on the internalization and dissemination of human norovirus surrogates in growing romaine lettuce. Appl. Environ. Microb. 81:4791-4800.

DiCaprio, E., A. Purgianto, Y. Ma, J. Hughes, X. Dai, and J. Li. 2015c. Attachment and localization of human norovirus and animal caliciviruses in fresh produce. Int. J. Food Microbiol. 211:101-108.

EC (European Commission). 2017. Commission notice on guidance document on addressing microbiological risks in fresh fruits and vegetables at primary production through good hygiene (2017/C 163/01). Official Journal of the European Union 163: 1-40.

Fuster, N., R.M. Pintó, C. Fuentes, N. Beguiristain, A. Bosch, and S. Guix. 2016. Propidium monoazide RTqPCR assays for the assessment of hepatitis A inactivation and for a better estimation of the health risk of contaminated waters. Water Res. 101:226-232. 
Gómez-López, V.M., A. Rajkovic, P. Ragaert, N. Smigic, and F. Devlieghere. 2009. Chlorine dioxide for minimally processed produce preservation: a review. Trends Food Sci. Technol. 20:17-26.

Hamilton, A.J., F. Stagnitti, R. Premier, A.-M. Boland, and G. Hale. 2006. Quantitative microbial risk assessment models for consumption of raw vegetables irrigated with reclaimed water. Appl. Environ. Microb. 72:3284-3290.

Hamza, I.A., L. Jurzik, K. Überla, and M. Wilhelm. 2011. Methods to detect infectious human enteric viruses in environmental water samples. Int. J. Hyg. Envir. Heal. 214:424-436.

Hennechart-Collette, C., S. Martin-Latil, L. Guillier, and S. Perelle. 2015. Determination of which virus to use as a process control when testing for the presence of hepatitis A virus and norovirus in food and water. Int. J. Food Microbiol. 202:57-65.

Hewitt, J., M. Leonard, G.E. Greening, and G.D. Lewis. 2011. Influence of wastewater treatment process and the population size on human virus profiles in wastewater. Water Res. 45:6267-6276.

Hirneisen, K.A., and K.E. Kniel. 2013. Norovirus Surrogate Survival on Spinach During Preharvest Growth. Phytopathology 103:389-394.

International Organization for Standardization. 2017. ISO 15216-1:2017. Microbiology of food and animal feed. Horizontal Method for Determination of Hepatitis A Virus and Norovirus in Food Using Real-Time RT-PCR. Part 1: Method for quantification.

Jin, M., Z.-G. Zhao, X.-W. Wang, Z.-Q. Shen, L. Xu, Y.-M. Yu, et al. 2012. The 40$80 \mathrm{nt}$ region in the $5^{\prime}$-NCR of genome is a critical target for inactivating poliovirus by chlorine dioxide. J. Med. Virol. 84:526-535.

Katayama, H., E. Haramoto, K. Oguma, H. Yamashita, A. Tajima, H. Nakajima, and S. Ohgaki. 2008. One-year monthly quantitative survey of noroviruses, enteroviruses, and adenoviruses in wastewater collected from six plants in Japan. Water Res. 42:1441-1448. 
527 Kingsley, D.H., Vincent, E.M., Meade, G.K., Watson, C.L., Fan, X. 2014. Inactivation 528 of human norovirus using chemical sanitizers. Int. J. Food Microbiol. 171:94-99.

529

530

531

532

533

534

535

536

537

538

539

540

541

542

543

544

545

546

547

548

549

550

551

552

553

554

Kitajima, M., B.C. Iker, I.L. Pepper, and C.P. Gerba. 2014. Relative abundance and treatment reduction of viruses during wastewater treatment processes Identification of potential viral indicators. Sci. Total Environ. 488-489:290-296.

Knight, A., D. Li, M. Uyttendaele, and L.A. Jaykus. 2013. A critical review of methods for detecting human noroviruses and predicting their infectivity. Crit. Rev. Microbiol. 39:295-309.

Kobayashi, N., M. Oshiki, T. Ito, T. Segawa, M. Hatamoto, T. Kato, et al. 2017. Removal of human pathogenic viruses in a down-flow hanging sponge (DHS) reactor treating municipal wastewater and health risks associated with utilization of the effluent for agricultural irrigation. Water Res. 110:389-398.

Kokkinos, P., Kozyra, I., Lazic, S., Bouwknegt, M., Rutjes, S., Willems, K., et al. 2012. Harmonised Investigation of the Occurrence of Human Enteric Viruses in the Leafy Green Vegetable Supply Chain in Three European Countries. Food Environ. Virol. 4:179-191.

Leifels, M., L. Jurzik, M. Wilhelm, and I.A. Hamza. 2015. Use of ethidium monoazide and propidium monoazide to determine viral infectivity upon inactivation by heat, UV- exposure and chlorine. Int. J. Hyg. Environ. Health 218:686-93.

Li, D., A., De Keuckelaere, and M. Uyttendaele. 2015. Fate of foodborne viruses in the "farm to fork" chain of fresh produce. Compr. Rev. Food Sci. Food Saf. 14:755770.

Lim, M.Y., J.-M. Kim, and G.P. Ko. 2010. Disinfection kinetics of murine norovirus using chlorine and chlorine dioxide. Water Res. 44:3243-3251.

López-Gálvez, F., A. Allende, A. Martinez-Sanchez, J.A. Tudela, M.V. Selma, and M.I. Gil. 2010. Suitability of aqueous chlorine dioxide versus sodium hypochlorite as an effective sanitizer for preserving quality of fresh-cut lettuce while avoiding byproduct formation. Postharvest Biol. Tec. 55:53-60. 
López-Gálvez, F., P. Truchado, G. Sánchez, R. Aznar, M.I. Gil, and A. Allende. 2016. Occurrence of enteric viruses in reclaimed and surface irrigation water: relationship with microbiological and physicochemical indicators. J. Appl. Microbiol. 121:1180-1188.

López-Gálvez, F., Gil, M.I., Meireles, A., Truchado, P., and Allende, A. Demonstration tests of irrigation water disinfection with chlorine dioxide in open field cultivation of baby spinach. J. Sci. Food Agric. 98: 2973-2980.

Moreno, L., R. Aznar, and G. Sánchez. 2015. Application of viability PCR to discriminate the infectivity of hepatitis A virus in food samples. Int. J. Food Microbiol. 201:1-6.

Morsy El-Senousy, W., S. Guix, I. Abid, R.M. Pinto, and A. Bosch. 2007. Removal of astrovirus from water and sewage treatment plants, evaluated by a competitive reverse transcription-PCR. Appl. Environ. Microbiol. 73:164-167

Parshionikar, S., I. Laseke, and G.S. Fout. 2010. Use of propidium monoazide in reverse transcriptase PCR to distinguish between infectious and noninfectious enteric viruses in water samples. Appl. Environ. Microbiol. 76:4318-4326.

Pérez-Rodríguez, F., P. González-García, A. Valero, M. Hernández, and D. RodríguezLázaro. 2014. Impact of the prevalence of different pathogens on the performance of sampling plans in lettuce products. Int. J. Food Microbiol. 184:69-73.

Prevost, B., M. Goulet, F.S. Lucas, M. Joyeux, L. Moulin, and S. Wurtzer. 2016. Viral persistence in surface and drinking water: Suitability of PCR pre-treatment with intercalating dyes. Water Res. 91:68-76.

Quijada, N.M., G. Fongaro, C.R.M. Barardi, M. Hernández, and D. Rodríguez-Lázaro. 2016. Propidium monoazide integrated with qPCR enables the detection and enumeration of infectious enteric RNA and DNA viruses in clam and fermented sausages. Front. Microbiol. 7(DEC), 2008.

Randazzo, W., F. López-Gálvez, A. Allende, R. Aznar, G. Sánchez. 2016. Evaluation of viability PCR performance for assessing norovirus infectivity in fresh-cut vegetables and irrigation water. Int. J. Food Microbiol. 229:1-6. 
584 Randazzo, W., Piqueras, J., Rodríguez-Díaz, J. Aznar, R., Sánchez, G. 2018 a. 585 Improving efficiency of viability-qPCR for selective detection of infectious HAV 586 in food and water samples. J. Appl. Microbiol. 124, 958-964.

587

Randazzo, W., Khezri, M., Ollivier, J., Le Guyader, F.S., Rodríguez-Díaz, J., Aznar, R., Sánchez, G. 2018b. Optimization of PMAxx pretreatment to distinguish between human norovirus with intact and altered capsids in shellfish and sewage samples. Int. J. Food Microbiol., 266, 1-7.

Reitz, S.R., R.A. Roncarati, C.C. Shock, H. Kreeft, and J. Klauzer. 2015. Chlorine dioxide injection through drip irrigation reduces Escherichia coli. 2015 ASABE/IA Irrigation Symposium: Emerging Technologies for Sustainable Irrigation. Proceedings of the 10-12 November 2015 Symposium, Long Beach, California USA. Published by ASABE St. Joseph, Michigan, USA. Publication date November 10, 2015. ASABE Publication No. 701P0415.

Rusiñol, M., X. Fernandez-Cassi, N. Timoneda, A. Carratalà, J.F. Abril, C. Silvera, et al. 2015. Evidence of viral dissemination and seasonality in a Mediterranean river catchment: Implications for water pollution management. J. Environ. Manage. 159: 58-67.

Sales-Ortells, H., X. Fernandez-Cassi, N. Timoneda, W. Durig, R. Girones, and G. Medema. 2014. Health risks derived from consumption of lettuces irrigated with tertiary effluent containing norovirus. Food. Res. Int. 68:70-77.

Sano, D., R.M. Pinto, T. Omura, and A. Bosch. 2010. Detection of oxidative damages on viral capsid protein for evaluating structural integrity and infectivity of human norovirus. Environ. Sci. Technol. 44:808-812.

Sigstam, T., Gannon, G., Cascella, M., Pecson, B. M., Wigginton, K. R., and Kohn, T. 2013. Subtle differences in virus composition affect disinfection kinetics and mechanisms. Appl. Environ. Microbiol. 79:3455-3467.

Van Haute, S., I. Sampers, L. Jacxsens, and M. Uyttendaele. 2015. Selection Criteria for Water Disinfection Techniques in Agricultural Practices. Crit. Rev. Food Sci. 11:1529-1551. 
613 WEAH (Water Education Alliance for Horticulture). 2016. Treatment Technologies: 614 Chlorine dioxide. Available at: http://watereducationalliance.org/keyinfo.asp. $615 \quad$ Accessed 26 October 2016.

616 Wei, J., Y. Jin, T. Sims, and K.E. Kniel. 2010. Manure- and biosolids-resident murine 617 norovirus 1 attachment to and internalization by romaine lettuce. Appl. Environ. $618 \quad$ Microbiol. 76:578-583.

619 WHO (World Health Organization). 2006. Wastewater Use in Agriculture. In: World 620 Health Organization, editor. Guidelines for the safe use of wastewater, excreta and 621 greywater, Vol. II. WHO, Geneva.

622 Wigginton, K.R., Pecson, B.M., Sigstam, T., Bosshard, F., and Kohn, T. 2012. Virus 623 inactivation mechanisms: impact of disinfectants on virus function and structural 624 integrity. Envir. Sci. Tech. 46:12069-12078.

625 Xue, B., M. Jin, D. Yang, X. Guo, Z. Chen, Z. Shen, et al. 2013. Effects of chlorine and 626 chlorine dioxide on human rotavirus infectivity and genome stability. Water Res. $627 \quad 47: 3329-3338$.

628 Yeap, J.W., Kaur, S., Lou, F., DiCaprio, E., Morgan, M., Linton, R., Li, J. 2016. 629 Inactivation kinetics and mechanism of a human norovirus surrogate on stainless 630 steel coupons via chlorine dioxide gas. Appl. Environ. Microbiol. 82:116-123. 


\section{Figure captions}

632 Figure 1. Performance of RT-qPCR and PMAxx-RT-qPCR to discriminate between 633 potentially infectious and $\mathrm{ClO}_{2}$-treated norovirus GI (black bars), GII (grey bars) and

634 astrovirus (white bars) in PBS (panel A) and secondary effluent water (panel B). 635 Different letters denote significant differences among treatments for each virus $(\mathrm{p}<$ $6360.05)$. 
637 Table 1. Physicochemical characteristics of the secondary effluent of a wastewater 638 treatment plant (untreated) and $\mathrm{ClO}_{2}$ treated secondary effluent $\left(\mathrm{ClO}_{2}\right.$ treated) used for 639 lettuce irrigation. Data are mean \pm standard deviation of two trials performed between 640 June and August 2016. ORP: Oxidation-reduction potential; TOC: Total organic carbon; 641 UV254: Absorbance at $254 \mathrm{~nm}$.

\begin{tabular}{ccc}
\hline Parameters & Untreated & ClO $_{2}$ treated \\
\hline $\mathrm{pH}$ & $7.7 \pm 0.1$ & $7.4 \pm 0.1 \mathrm{~ns}$ \\
Temperature $\left({ }^{\circ} \mathrm{C}\right)$ & $27.2 \pm 1.4$ & $27.2 \pm 1.5 \mathrm{~ns}$ \\
ORP & $343 \pm 96$ & $411 \pm 178 \mathrm{~ns}$ \\
$\mathrm{UV} 254\left(\mathrm{~cm}^{-1}\right)$ & $0.26 \pm 0.06$ & $0.24 \pm 0.06 \mathrm{~ns}$ \\
$\mathrm{TOC}(\mathrm{mg} / \mathrm{L})$ & $13.1 \pm 3.3$ & $14.4 \pm 2.8 \mathrm{~ns}$ \\
Initial $\mathrm{ClO}_{2}(\mathrm{mg} / \mathrm{L})^{*}$ & $<0.02$ & $5.6 \pm 2.4$ \\
Residual $\mathrm{ClO}_{2}(\mathrm{mg} / \mathrm{L})$ & $<0.02$ & $0.51 \pm 0.41 * *$ \\
\hline
\end{tabular}


Table 2. Prevalence of human norovirus genogroup I (NoV GI) and II (NoV GII) and human astrovirus (HAstV) analyzed by RT-qPCR in the secondary effluent of wastewater treatment plant (untreated) and $\mathrm{ClO}_{2}$ treated secondary effluent $\left(\mathrm{ClO}_{2}\right.$ treated) used for lettuce irrigation. Samples were not pre-treated with PMAxx. Data are expressed as log genome copies/L.

\begin{tabular}{ccccccccc}
\hline \multicolumn{3}{c}{ Untreated } & \multicolumn{4}{c}{ ClO $_{2}$ treated } \\
\hline \multirow{3}{*}{ NoV GI } & Prevalence (\%) & Median & Minimum & Maximum & Prevalence (\%) & Median & Minimum & Maximum \\
NoV GII & 75.0 & 5.00 & 4.08 & 5.15 & $58.3 \mathrm{~ns}$ & 4.86 & 4.12 & 5.25 \\
HAstV & 66.7 & 5.53 & 4.43 & 5.94 & $50.0 \mathrm{~ns}$ & 5.30 & 5.15 & 5.65 \\
& 33.3 & 5.52 & 4.04 & 7.29 & $33.3 \mathrm{~ns}$ & 6.64 & 6.39 & 6.80 \\
\hline
\end{tabular}

${ }^{\mathrm{a}}$ Proportion of positive samples from each type of water $(\mathrm{n}=12)$. * significant difference (chi-square test, $\left.\mathrm{p}<0.01\right)$ in the prevalence between untreated and treated samples. ns: not significant. 
Table 3. Log genome copies/L (Mean \pm SD) in the secondary effluent of wastewater treatment plant (untreated) and $\mathrm{ClO}_{2}$ treated secondary effluent $\left(\mathrm{ClO}_{2}\right.$ treated) used for lettuce irrigation samples analyzed by RT-qPCR with and without the use of PMAxx/Triton. Data are expressed as log genome copies/L.

\begin{tabular}{ccccc}
\hline & \multicolumn{2}{c}{ Untreated } & \multicolumn{2}{c}{ ClO $_{2}$ treated } \\
& PMAxx & No PMAxx & PMAxx & No PMAxx \\
\hline NoV GI & $4.65 \pm 0.54$ & $4.75 \pm 0.39 \mathrm{~ns}$ & $4.19 \pm 0.37$ & $4.84 \pm 0.34 *$ \\
NoV GII & $5.47 \pm 0.42$ & $5.28 \pm 0.23 \mathrm{~ns}$ & $5.43 \pm 0.09$ & $5.21 \pm 0.28 \mathrm{~ns}$ \\
HAstV & $7.04 \pm 0.15$ & $7.14 \pm 0.20 \mathrm{~ns}$ & $6.50 \pm 0.31$ & $6.62 \pm 0.19 \mathrm{~ns}$
\end{tabular}

*significant difference $(\mathrm{p}<0.01)$ between samples treated and untreated with PMAxx. ns: not significant. 
Figure 1.
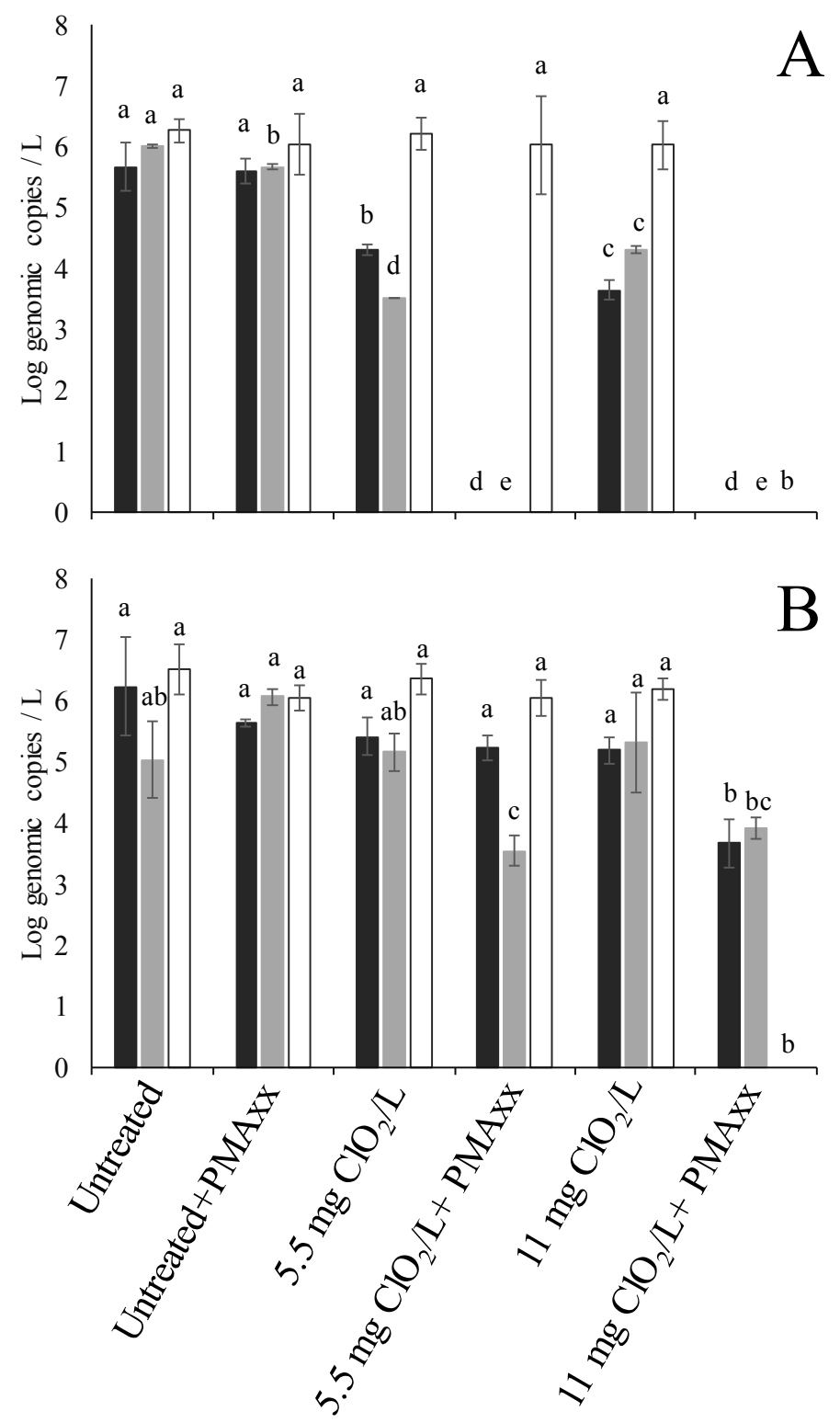
Supplementary information 1. Physicochemical characteristics of PBS and secondary effluent water before and during treatment with $\mathrm{ClO}_{2}$ at lab scale.

\begin{tabular}{|c|c|c|c|c|c|c|}
\hline Suspension media & $\begin{array}{c}\text { Initial } \mathrm{ClO}_{2} \text { dose } \\
(\mathrm{mg} / \mathrm{L})\end{array}$ & $\begin{array}{l}\text { Time } \\
\text { (min) }\end{array}$ & $\mathbf{p H}$ & $\begin{array}{l}\text { ORP } \\
(\mathrm{mV})\end{array}$ & $\begin{array}{c}\text { Temperature } \\
\left({ }^{\circ} \mathrm{C}\right)\end{array}$ & $\begin{array}{c}\mathrm{ClO}_{2} \\
(\mathrm{mg} / \mathrm{L})\end{array}$ \\
\hline \multirow{4}{*}{ PBS } & \multirow{4}{*}{5.5} & $0^{*}$ & 7.32 & 234 & 25.4 & \\
\hline & & 1 & 7.35 & 742 & 25.5 & \\
\hline & & 3 & 7.39 & 747 & 25.6 & \\
\hline & & 6 & 7.42 & 741 & 25.7 & 3.8 \\
\hline \multirow{4}{*}{ Secondary treatment effluent water } & \multirow{4}{*}{5.5} & $0^{*}$ & 7.43 & 399 & 24.4 & \\
\hline & & 1 & 7.41 & 688 & 24.5 & \\
\hline & & 3 & 7.40 & 659 & 24.6 & \\
\hline & & 6 & 7.39 & 607 & 24.7 & 0.03 \\
\hline \multirow{4}{*}{ PBS } & \multirow{4}{*}{11} & $0^{*}$ & 7.44 & 278 & 25.6 & \\
\hline & & 1 & 7.44 & 764 & 25.6 & \\
\hline & & 3 & 7.44 & 765 & 25.7 & \\
\hline & & 6 & 7.52 & 764 & 25.8 & 9.29 \\
\hline \multirow{4}{*}{ Secondary treatment effluent water } & \multirow{4}{*}{11} & $0^{*}$ & 7.81 & 402 & 25.6 & \\
\hline & & 1 & 7.56 & 723 & 25.7 & \\
\hline & & 3 & 7.53 & 712 & 25.8 & \\
\hline & & 6 & 7.54 & 703 & 25.9 & 3.22 \\
\hline
\end{tabular}

*Before adding $\mathrm{ClO}_{2}$. 